\title{
Announcement
}

\section{Serono Foundation for the Advancement of Medical Science Workshop on 'Inhibins, Activins and Follistatins'}

Siena (Tuscany, Italy), J uly 3-4, 2003

Scientific Committee: David de Kretser (AU), Nigel P. Groome (UK),

Felice Petraglia (Italy), Alan Schneyder (USA), Wylie Vale (USA)

Topics: Proteins and receptors, impact on reproduction and development, cell differentiation and cancer, inflammation.

Abstract submission: Deadline January 31, 2003

Further information: http://www.unisi.it/eventi/inhibin2003

Contacts:

Pasquale Florio, Donato D’Antona, Stefano Luisi

Obstetrics and Gynecology, University of Siena

Viale Bracci, I-53100 Siena (Italy)

Fax +390577233 454, E-Mail obgyn@unisi.it 